\section{Recent Excavations in Roman Britain}

COLONEL C. D. DREW, who is in charge of the 1 excavation of the Roman house-site in Colliton Park, Dorchester (see Nature, Aug. 21, p. 311), reports the interesting and unusual discovery of the leg of a Roman chair, made of Kimmeridge shale. It was found beneath the damaged floor of the heated room, of which the tessellated pavement, as previously reported, had collapsed. It was found that stonework supporting the floor had sunk where the filling of a pit had proved less compact than the surrounding chalk. The chair leg was found deep down in the filling of the pit, which was of considerable depth. It is richly carved with the head of an open-mouthed animal, and the foot terminates in a lion's claw. It is in an excellent state of preservation, but requires skilled treatment to prevent flaking, before it can be placed on exhibition in the Dor. chester Museum. As articles of Roman furniture are of rare occurrence in Britain, the find is of consider. able interest. Among other recent finds on this site are thirty bronze coins of the fourth century A.D. from a trial trench. The excavation committee has approached the County Council with the view of securing the preservation of the remains of this Roman house, and the matter is now under the consideration of a sub-committee of the Council.

A large and important collection of Roman relics has been discovered by the excavation section of the Thoroton Society of Nottingham on the corporation housing estate at Broxtowe in the old part of the city. According to report (The Times, Oct. 4), the finds include a grave containing bones and Roman coins, brooches, a silver spoon, rings, knives and dice of wood. Among the broken pottery is some highly glazed Samian ware of the first century, decorated with hares and hounds. A portion of the Roman road was uncovered and a quantity of oyster shells was found.

At Lincoln the demolition of an eighteenth century house abutting on the Newport Arch, the only remaining Roman arch in Britain which spans a public road, has brought to light evidence which reveals that the arch in its original form has a postern gate on either side. There is at present on the eastern side a postern gate which is used by foot passengers; but when the western side of the arch was laid bare by the recent work of demolition, the beginning of the spring of the second postern gate was disclosed. It corresponds with the gateway on the eastern side. The arch was scheduled as an ancient monument in 1924 ; and according to a report in The Times of October 4, it is hoped to modify the rebuilding scheme in such a manner as to allow for the restoration of the postern gate on the west side.

Excavation on what is supposed to be the site of the Roman town of Sulloniacæ at Brockley Hill, Middlesex, two miles north of Edgware on the east side of Watling Street, points to the possibility that it may have been originally a native town or oppidum, of which the population shifted after the conquest, attracted by the facilities for traffic offered by this trunk road. The investigation is being carried out by the London and Middlesex Archæological Society with the co-operation of the Stanmore and Edgware Historical Society under the direction of Mr. F. Cottrill, local secretary of the Society of Antiquaries (The Times, Oct. 1). The site lies at the east end of a gravel ridge, which rises to a height of five hundred feet.
The arrangement of banks and ridges at Brockley Hill recalls the site of Prae Wood at St. Albans, excavated by Dr. R. E. Mortimer Wheeler. A Belgic potsherd has been found in one of the ditches. A trench dug near the east side of the road gives a section of two depressions, twenty feet and nine feet wide respectively, in the natural clay. The filling of these depressions produced pottery of common late first and early second century types in considerable quantity, the common 'screw-neck' flagon predominating. Some sherds showed signs of over-firing, while some almost complete pots had been thrown away on account of flaws in manufacturing. This, with the evidence of masses of baked clay, brick and tile 'wasters', points to the existence here of a roadside industrial settlement for the making of bricks and pottery. Another trench revealed a Romari occupation layer of the first century, which had been partly removed by seventeenth century and early eighteenth century builders. Exploration farther away from the road produced no evidence of occupation beyond a small Belgic pit. No traces of a Roman building have been found. Evidently the kilns had been placed at the east end of the town to avoid the fumes which would be carried by the prevailing south-west wind.

\section{University Events}

GLASGow.-Dr. Paul Bacsich has been appointed lecturer in embryology in the Department of Anatomy, and Dr. H. Ellis C. Wilson lecturer in pathological biochemistry at the Royal Hospital for Sick Children.

LoNDON.-The following announcements have been made from University College: Prof. S. Sugden, formerly of Birbeck College, succeeds Prof. F. G. Donnan in the chair of chemistry; Prof. C. K. Ingold becomes director of the Chemistry Laboratories.

The Department of Geography has been moved to new, freshly equipped quarters in Foster Court (the block of buildings on the south side of the College, acquired in 1931).

The University has accepted the benefaction of the late Mrs. Florence Joy Weldon, of Oxford, who bequeathed her residuary estate upon trust for the foundation of a professorship of biometry for the higher statistical study of biological problems. The chair has been established at University College, the first holder being Prof. J. B. S. Haldane (see p. 612).

Reading.-Dr. G. W. Scott Blair, of Rothamsted Experimental Station, has been appointed head of the Dairy Chemistry Department of the National Institute for Research in Dairying in succession to Captain J. Golding, who has retired.

St. Andrews.--In connexion with the celebration of the quatercentenary of St. Mary's College on September 28 the honorary degree of LL.D. was conferred, among others, on the following : R. F. J. Fairlie, architect for the restoration of St. Salvator's Chapel, St. Andrews, and of the Scottish National Library ; the Right Hon. Sir John Simon, Chancellor of the Exchequer; Prof. G. F. Stout, formerly professor of logic and metaphysics ; and Sir Leonard Woolley, director of the Joint Expedition of the British Museum and the Museum of the University of Pennsylvania to Mesopotamia. 